\title{
EFFICIENCY OF RESOURCE USE IN SMALL-SCALE WHITE SHRIMP (PENAEUS VANNAMEI ) PRODUCTION IN LAMONGAN REGENCY, EAST JAVA PROVINCE, INDONESIA
}

\author{
Riski A. Lestariadi, Ratya Anindita, Researchers ${ }^{1}$ \\ Sutonya Thongrak, Researcher ${ }^{2}$ \\ ${ }^{1}$ Brawijaya University, Indonesia \\ ${ }^{2}$ Prince of Songkla University, Thailand \\ E-mail: risk.agung@gmail.com
}

Received September 10, 2012

\begin{abstract}
This study carried out to determine the efficiency of recourses use in white shrimp (Penaeus Vannamei) production in Lamongan Regency, East Java Province, Indonesia. The simple random sampling technique used to select 125 small-scale white shrimp farmers from six-study areas in Lamongan Regency. The white shrimp production function was estimated using Ordinary Least Square (OLS) technique. The results indicated that Double Log production function had the best fit in explaining the relationship between output of white shrimp and inputs used. The coefficient of determination $(R 2=$ 0.846) indicated that the eighty-four point six percent of variation in output of white shrimp was explained by the independent variables in the model. Findings showed that labor, fertilizer, feed and stocking density are significant determinants of production inputs. Moreover, the estimates of the ratio of the value of marginal product (VMP) to marginal factor cost (MFC) revealed that the non-optimal combination of inputs among the white shrimp farmers, it showed that the aquaculture farms resources were inefficiently utilized for labor, feed and stocking density by 1.94, 1.93 and 171.4 respectively, while fertilizer showed otherwise by 0.11 or over utilized.
\end{abstract}

\section{KEY WORDS}

Production efficiency; White shrimp; Farming; Intensive technology; Small-scale; East Java Province.

Aquaculture plays an important role to Indonesian fisheries in providing employment, food security, income, foreign exchange and securing livelihood for the people (Nurdjana, 2006, Herianto, 2010). In addition, aquaculture activities can also reduce pressure on fishery resources and supporting rural economic development (FAO, 2010). According to Marine and Fisheries Statistic (MMAF, 2010), millions of people in Indonesia depend on aquaculture for their livelihood. There were 1,099,684 households involved in the aquaculture industry, representing around $60.17 \%$ of the total number of people employed in the fisheries sector in 2009.

Indonesian aquaculture grew rapidly with an average growth rate of $21.47 \%$ between 2005 and 2009 (MMAF, 2010). According to Dyspriani (2007), the main activity and source of investment in aquaculture is shrimp farming. Shrimp production has grown significantly from 280,629 tons in 2005, and then production in 2009 reported to have risen to 338,062 tons. This represents an average annual increase of $5.73 \%$ in quantity since 2005 . Increase in shrimp production triggered by export, local consumer demand and the Government policy on fishery revitalization.

The shrimp species that cultivated in Indonesia are still limited. At first, the most of the shrimp farmers in Indonesia cultivate black tiger shrimp (Penaeus monodon). However, since they faced the harvest failure during 1990 until 2000 due to the outbreaks of shrimp diseases, some of them tried to cultivate white shrimp (Penaeus vannamei) and rostris shrimp (Penaeus stylirostris). These shrimps are not native species; the Indonesian Government has imported from Hawai and Taiwan in 2000 and 2001 respectively. The fast growth of white shrimp farming recently is due to its rapid reproduction than black tiger 
shrimp. White shrimp has also stronger endurance and can be cultivated with higher biomass density (Poernomo, 2004). Under the shrimp revitalization program in 2005 , the extensive black tiger brackish water ponds with area of 140,000 ha $(40 \%$ of extensive brackish water ponds) shifted to extensive white shrimp farming with target 0.6-1.5 ton/ha/years. Moreover, 8,000 ha of intensive black tiger brackish water ponds shifted to intensive white shrimp farming with the target 20-30 ton/ha/years (MMAF, 2006).

In general, shrimps are cultivated in brackish water ponds. Some characteristics of shrimp farming in Indonesia are small-scale, local ownership, low capital, technology, and productivity. According to size of management and input factors, shrimp farming is classified into small scale, medium and large scale. Small-scale farms are typically less than five ha in total brackish water pond areas usually operated by a family group and sometimes hired labor, simple facilities, and low level of management. In term of technology used in shrimp farming, it varies from location to location, depending on the level of technology applied. Based on stocking density and other supporting factor, shrimp farming in Indonesia has known four technologies in the shrimp cultivation, which are traditional, extensive, semi intensive and intensive.

In 2005, the Indonesian Government has stated that Indonesia should consider white shrimp as a source of raw materials for processing industry and enhancement of export volume from aquaculture commodities. In order to support Government policy to increase national shrimp production, white shrimp farmers in Lamongan Regency using intensive technology in their shrimp cultivation. Intensive technology is high cost technology. On the other hand, the white shrimp farmers in this area dominated with small-scale farmers. In production, small-scale farmers often faced with the problem of scarcity of resources as their inputs of production due to they have limited capital and brackish water pond area. The level of efficiency in using resources is one of the important factors to improve the aquaculture farms production. Efficiency of resources used such as labor, fertilizer, feed, stocking density and other inputs will ensure sustainable of production.

This study attempts to provide some useful information towards increasing white shrimp production that using intensive technology. Thus, this study examines the efficiency of resource use in white shrimp production on small-scale aquaculture farms.

\section{METHODOLOGY}

The study conducted in Lamongan Regency, East Java Province, Indonesia. Currently, East Java Province is the third largest shrimpproducing province in Indonesia. Lamongan Regency was selected because it is one of the largest white shrimp producing area in East Java Province. Together with milkfish, white shrimp is the main commodities in this region. In 2010, white shrimp production reached 19,110 tons or $52.9 \%$ of total aquaculture production.

The total 125 small-scale white shrimp farmers from six-study areas (Labuhan, Brengkok, Sedayu Lawas, Kranji, Tlogosadang, and Kandang Semangkon) were selected using simple random sampling. Data collection was conducted in November 2011 to January 2012. This study considers four explanatory variables in modeling the production function for white shrimp production. Based on a technical knowledge, the four inputs considered important in explaining variation in output of white shrimp, these are quantities of labor, fertilizer, feed and stocking density. The variables considered are (1) labor includes both family and hired labor used for land preparation, pre and post aquaculture operations, harvesting and marketing. It will measure in labordays used for white shrimp production per ha. (2) Fertilizer includes all fertilizers used by the aquaculture farm for white shrimp production and will be measured in kg per ha. (3) Feed is the quantity of formulated feed applied to the white shrimp production, measured in $\mathrm{kg}$ per ha. (4) Stocking density is the number of white shrimp fries applied to the white shrimp production, measured in fry per ha. Inputs and output price also taken based on the prevailing market price in study areas during data collection.

To determine the relationship between output of white shrimp and the selected input variables, data were analyzed using the Ordinary Least Square (OLS) multiple regression technique. The Exponential, Double Log and Semi Log functional forms were used to determine which of the forms would best fit the relationship between output of white shrimp and the input as explanatory variables. The functional forms fitted specified equation below: 
a. Exponential

$$
\begin{aligned}
& \log Y=b_{0}+b_{1} X_{1}+b_{2} X_{2}+b_{3} X_{3}+b_{4} X_{4}+e \\
& \text { b. Double Log } \\
& \log Y=b_{0}+b_{1} \log X_{1}+b_{2} \log X_{2}+b_{3} \log X_{3}+b_{4} \log X_{4}+e \\
& \text { c. Semi Log } \\
& Y=b_{0}+b_{1} \log X_{1}+b_{2} \log X_{2}+b_{3} \log X_{3}+b_{4} \log X_{4}+e
\end{aligned}
$$

Where:

$Y=$ output of white shrimp (kg per ha);

$X_{1}=$ labor (man-days per production cycle);

$X_{2}=$ fertilizer (kg per ha per production cycle);

$X_{1}=$ feed (kg per ha per production cycle);

$X_{1}=$ stocking density (white shrimp fry per ha per production cycle);

$b=$ regresion coefficient to estimate;

$e=$ error term.

The lead equation was chosen not only based on the value of the coefficient determination $\left(\mathrm{R}^{2}\right)$ and the significance of the regression parameters but also other econometric criteria, such as fulfillment to the assumptions of ordinary least square. At last, the Double Log functional form is the best for estimation of the parameters

used in efficiency analysis. Efficiency of resource use was determined by ensuring the ratio of the value of marginal product to the inputs price was equal to one. Efficiency of resources used employed in white shrimp production expressed as follows:

$$
\frac{M P P . P_{\bar{Y}}}{P_{\bar{X}}}=1
$$

Equation 4 can be rewritten as:

$$
\frac{V M P}{P_{\bar{X}}}=1
$$

Where:

$P_{\bar{Y}}=$ average of output price (IDR per $\mathrm{kg}$ );

$P_{\bar{X}}=$ average of unit input price (IDR per unit inputs);

$M P P=$ marginal physical product;

$V M P=$ value of marginal product.

Three scenarios can be observed:
a. $\frac{V M P}{P_{\overline{X_{1}}}}=1 \quad X_{i}$ is optimal
b. $\quad \frac{V M P}{P_{\overline{X_{l}}}}<1 \quad X_{i}$ is over utilized
c. $\frac{V M P}{P_{\overline{X_{l}}}}>1 \quad X_{i}$ is under utilized

According to Debertin (2002), Soekartawi (2003) and Ugwumba (2010), a given resource optimally allocated when there is no divergence between its value of marginal product (VMP) and its acquisition cost (i.e. marginal factor cost or MFC). A firm maximizes its profit with respect to an input if the ratio of its VMP to MFC is unity. If the VMP is greater than the unit input price,

it implies under utilization of the input and this indicates the scope for raising output efficiently by increasing the use of that particular input. Otherwise, if the value of marginal product is less than the input price, it implies over utilized and the firm should be reduced using particular input in production process. 


\section{RESULTS AND DISCUSSION}

Socio-economic Characteristics of White Shrimp Farmers. Socio-economic characteristics of white shrimp farmers in the study areas in Table 1 showed that the white shrimp farmers whose ages less than 39 years constituted the majority. Overall, $67.2 \%$ fall into the productive age group of $20-49$ years. Most of white shrimp farmers had the household size between four to six, but the size ranged from one to eight. In the study area, fish farming has become hereditary occupation. They have been cultivating milkfish for the long time before white shrimp farming started in 2000. More than $80 \%$ of sample stated that the white shrimp farming has become their main occupation, while the remaining stated as supplementary occupation. Furthermore, only $33.6 \%$ of white shrimp farmers have access to credit services due to lack of knowledge, restrictive procedure, lack of collateral and high interest rate.

Table 1 - Socio economic characteristics of white shrimp farmers

\begin{tabular}{|c|c|c|}
\hline Items & Frequency & $\%$ \\
\hline $\begin{array}{l}\text { Age (Years) } \\
-\quad \leq 39 \\
-\quad 40-49 \\
-\quad \geq 50\end{array}$ & $\begin{array}{l}48 \\
36 \\
41\end{array}$ & $\begin{array}{l}38.4 \\
28.8 \\
32.8\end{array}$ \\
\hline $\bar{x}$ & \multicolumn{2}{|c|}{43.8} \\
\hline $\begin{aligned} \text { Household Size (People) } \\
\begin{aligned}- & <4 \\
- & 4-6 \\
- & >6\end{aligned}\end{aligned}$ & $\begin{array}{l}58 \\
65 \\
2\end{array}$ & $\begin{array}{c}46.4 \\
52 \\
1.6\end{array}$ \\
\hline (1) & \multicolumn{2}{|c|}{3.6} \\
\hline $\begin{array}{c}\text { Occupation as White Shrimp Farmers } \\
-\quad \text { Main Occupation } \\
-\quad \text { Side Occupation }\end{array}$ & $\begin{array}{c}100 \\
25\end{array}$ & $\begin{array}{l}80 \\
25\end{array}$ \\
\hline $\begin{array}{l}\text { Access of Credit } \\
\quad-\quad \text { Have access to credit services } \\
-\quad \text { Do not have access to credit services }\end{array}$ & $\begin{array}{l}42 \\
83\end{array}$ & $\begin{array}{l}33.6 \\
66.4\end{array}$ \\
\hline $\begin{aligned} \text { Education (Years schooling) } \\
-\quad<6 \\
-\quad 6-9 \\
-\quad>9\end{aligned}$ & $\begin{array}{l}7 \\
67 \\
51\end{array}$ & $\begin{array}{c}5.6 \\
53.6 \\
40.8\end{array}$ \\
\hline 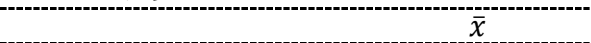 & \multicolumn{2}{|c|}{9.3} \\
\hline $\begin{aligned} \text { Experience in White Shrimp Farming (Years) } \\
-\quad<6 \\
-\quad 6-9 \\
-\quad>9\end{aligned}$ & $\begin{array}{l}59 \\
49 \\
17\end{array}$ & $\begin{array}{l}47.2 \\
39.2 \\
13.6\end{array}$ \\
\hline- & \multicolumn{2}{|c|}{6} \\
\hline $\begin{array}{l}\text { Land Holding (ha) } \\
\begin{aligned}-\quad & <1 \\
- & 1-2 \\
- & >2\end{aligned}\end{array}$ & $\begin{array}{l}91 \\
26 \\
8\end{array}$ & $\begin{array}{c}72.8 \\
20.8 \\
6.4\end{array}$ \\
\hline 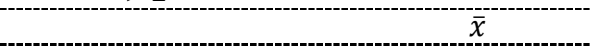 & \multicolumn{2}{|c|}{0.78} \\
\hline $\begin{array}{ll}\text { Number of Brackish Water Pond (Ponds) } \\
\begin{aligned}- & 1-2 \\
- & 3-4 \\
- & >4\end{aligned}\end{array}$ & $\begin{array}{c}104 \\
11 \\
10\end{array}$ & $\begin{array}{c}83.2 \\
8.8 \\
8\end{array}$ \\
\hline
\end{tabular}

One of the important and crucial aspects concerning planning decisions about production is the experience in white shrimp farming and education level of the white shrimp farmers. The white shrimp farmers in the study areas that have the senior high school certificate and the university degree reached $40.8 \%$ and $53.6 \%$ between six to nine years of schooling or junior high school level, while $5.6 \%$ in-group one to six years schooling or elementary school level. The results of the analysis revealed that $47.2 \%$ of white shrimp farmers had experience less than six years. However, $39.2 \%$ of the white shrimp farmers disclosed that they had experience between six to nine years, while $13.6 \%$ revealed that they had experience more than nine years.

The distribution of land holding in the study areas is shown in Table 1 which indicates that 
most of white shrimp farmers have the area of brackish water pond below one ha. The results revealed that $83.2 \%$ of white shrimp farmers had number of brackish water pond between one until two. The average brackish water pond sizes are $0.42 \mathrm{ha}$; this is small size for brackish water pond. Most of white shrimp farmers in study areas are small farmers; they have limited resources and technology to manage their pond. Small pond size allows them to maintain water quality and health of white shrimp easier. Moreover, small pond size requires fewer paddle wheels, means less investment required.

White Shrimp Farming and Production. In study areas, the white shrimp farmers were cultivating white shrimp twice a year, starting in May and November. The white shrimp fries require 110 to 130 days to grow up to the market size. The amount of white shrimp produced from brackish water pond per production cycles vary from places to places, which usually determined by the stocking density of white shrimp fry, natural mortality, level of management, and size of white shrimp when harvesting. Based on the results of the study, the average amount of white shrimp harvested was $5,451 \mathrm{~kg}$ per brackish water pond. Furthermore, the average productivity of white shrimp farming in the study areas was $13,116 \mathrm{~kg}$ per ha for the last production.

Table 2 - Inputs and Output Variables in White Shrimp Farming

\begin{tabular}{|c|c|c|c|c|c|}
\hline- & Unit & Min & Max & Mean & Price (IDR) \\
\hline Yield & $\mathrm{Kg} / \mathrm{ha}$ & 3,500 & 9,430 & 5,451 & 46,375 \\
\hline Labor & Man-days & 160 & 216 & 188 & 64,700 \\
\hline Fertilizer & $\mathrm{Kg} / \mathrm{ha}$ & 1,590 & 3,830 & 2,412 & 47,400 \\
\hline Feed & $\mathrm{Kg} / \mathrm{ha}$ & 6,300 & 13,200 & 9,036 & 13,350 \\
\hline Stocking Den. & Fry/ha & 190,000 & 560,000 & 353,271 & 55 \\
\hline
\end{tabular}

The four inputs were observed in white shrimp production process are labor, fertilizer, feed and stocking density. Labor mainly used to prepare and manage the brackish water pond. Regarding to labor using, the minimum value is 160 man-days and maximum arise to 216 mandays which are depended on the size of brackish water pond and stocking density. Fertilizer and white shrimp feed referred to the quantity of fertilizer and formulated feed used in white shrimp production. In practice, the cost of feed is the highest ones among the costs for all inputs in white shrimp production. On the average, one brackish water pond was using $2,412 \mathrm{~kg}$ of fertilizer and 9,036 kg of formulated feed, depending on the size and environmental condition of brackish water pond, stocking density, natural mortality and the feeding rate. In the study areas, the white shrimp cultivated in brackish water ponds with the different stocking density levels, the minimum value for stocking density is 190,000 and maximum arise to 560,000 fries per brackish water pond which is depended on the size of brackish water pond.

Table 3 - Problems in White Shrimp Farming

\begin{tabular}{|c|c|c|}
\hline Problems & Frequency & $\%$ \\
\hline Diseases & 47 & 37.6 \\
\hline Lack of Capital & 28 & 22.4 \\
\hline Insufficient Quality of White Shrimp Fry & 16 & 12.8 \\
\hline Low Price of White Shrimp & 12 & 9.6 \\
\hline Water Pollution from Human Activities & 9 & 7.2 \\
\hline High Production Costs & 8 & 6.4 \\
\hline Inappropriate Pond Design & 5 & 4 \\
\hline
\end{tabular}

The farmers interviewed to elicit the problems relating to various aspects in white shrimp production (Table 3 ). The main problem faced by the farmers in white shrimp production is white shrimp diseases. About $37.6 \%$ of white shrimp farmers stated that one of their brackish water ponds infected by White Spot Syndrome Virus (WSSV) or Infectious Myonecrosis Virus (IMV) in the last production cycle. Lack of capital to improve their production was the second problem raised by $22.4 \%$ of the farmers. The third problem was the quality of white shrimp fries $(12.8 \%)$. In general, white shrimp farmers in study areas using Specific Pathogen Free (SPF) white shrimp fries. Lack of knowledge in white 
shrimp farming and poor environmental management has triggered the spread of disease.

Efficiency Analysis. The multiple regression analysis carried out to examine the determinants of factors effecting output in aquaculture farms by small-scale farmers in Lamongan Regency. The results of the regression analysis of factors influencing output of white shrimps are show on Table 4. The results indicated that Double $\log$ functional form had the best fit in explaining the relationship between output of white shrimp and inputs used, the coefficient determination $\left(R_{2}=0.846\right)$ indicated that $84.6 \%$ of variation in output of white shrimp is explained by the independent variables, while the rest $15.4 \%$ of the variation was due to other variables that did not include in the model. The overall regression result was significant as $\mathrm{F}_{\text {Statistic }}$ value of 164.9585 and significant at $1 \%$ level of probability. This provides evidence that the combination of labor, fertilizer, feed and stocking density had an impact simultaneously on output of white shrimp in the study areas. Again, the Durbin Watson value of 1.99 , which is approximately equal to two, indicated the absence of multicollinearity.

Table 4 - Estimate of Double Log functional form

\begin{tabular}{|c|c|c|c|}
\hline Variables & Coefficient & t Statistic & Probability \\
\hline Constant & -10.121 & -10.146 & 0.0000 \\
\hline $\log \mathrm{X}_{1}$ & 1.653 & 10.923 & 0.0000 \\
\hline $\log X_{2}$ & 0.106 & 1.783 & 0.0770 \\
\hline $\log X_{3}$ & 0.589 & 7.643 & 0.0000 \\
\hline $\log X_{4}$ & 0.302 & 4.447 & 0.0000 \\
\hline F-Statistic & \multicolumn{2}{|c|}{164.958} & 0.0000 \\
\hline $\mathrm{R}^{2}$ & \multicolumn{3}{|c|}{0.846} \\
\hline $\mathrm{R}^{2} \mathrm{Adj}$ & \multicolumn{3}{|c|}{0.840} \\
\hline$D-W$ & \multicolumn{3}{|c|}{1.994} \\
\hline
\end{tabular}

The Double log functional form showed that all inputs positively related to the output of white shrimp. The estimated coefficients are positive; the coefficients of labor, fertilizer, feed, and stocking density are $1.653,0.106,0.589$ and 0.302 respectively. Furthermore, labor, feed, stocking density significantly affects the output of white shrimp at $1 \%$, while fertilizer at $10 \%$ level of probability. Thus, it can be inferred that for $1 \%$ increase in the use of labor from its present average level of 188 man days to 190 man days, output of white shrimp will increase by $1.65 \%$ that is by $89.9 \mathrm{~kg}$, ceteris paribus. Increasing by $1 \%$ in the use of fertilizer from its present average level of $2,412 \mathrm{~kg}$ to $2,437 \mathrm{~kg}$ will increase output of white shrimp, by $0.1 \%$ that is by $5,457 \mathrm{~kg}$, ceteris paribus. Moreover, increase by $1 \%$ in the use of feed from its present average level of $9,036 \mathrm{~kg}$ to $9,126 \mathrm{~kg}$ will increase output of white shrimp, by $0.5 \%$ that is by $5,483 \mathrm{~kg}$, ceteris paribus. For stocking density, increase by $1 \%$ from its present average level of 35,3271 white shrimp fry/ha to 35,6803 white shrimp fry/ha will increase output of white shrimp, by $0.3 \%$ that is by $5,468 \mathrm{~kg}$, ceteris paribus.

The value of marginal product (VMP) to marginal factor cost (MFC) ratios of resources in the production of white shrimp has been present in Table 5. From the findings of the study, it can be concluded that aquaculture farm resources were not efficiently utilized for white shrimp production. The allocative ratio for labor, fertilizer, feed, and stocking density was 1.94, 0.11, 1.93 and 171.4 respectively. By these results, labor, feed and stocking density were underutilized having allocative efficiency ratios greater than one while fertilizer with allocative efficiency ratio below one were over utilized. Lack of capital is one factor that led to the white shrimp farmers failed to use inputs in optimal proportions, this implies that there is potential for white shrimp farmers to improve on production by increase labor, feed and stocking density in their brackish water pond.

Table 5 Estimated Value of Marginal Product (VMP), Marginal Factor Cost (MFC) and Allocative Efficiency Ratios

\begin{tabular}{|c|c|c|c|c|}
\hline Inputs & VMP & MFC & Allocative Efficiency & Decisions \\
\hline $\mathrm{X}_{1}$ & 125,525 & 64,700 & 1.94 & Under Utilized \\
\hline $\mathrm{X}_{2}$ & 5,448 & 47,400 & 0.11 & Over Utilized \\
\hline $\mathrm{X}_{3}$ & 25,781 & 13,350 & 1.93 & Under Utilized \\
\hline $\mathrm{X}_{4}$ & 9,429 & 55 & 171.4 & Under Utilized \\
\hline
\end{tabular}


Further, the result explained that with other inputs held constant, increasing labor by one unit would increase total value product by IDR 125,525 . For another inputs, increasing feed and stocking density by one unit would increase total value product by IDR 25,781 and IDR 9,429 respectively. On the other side, fertilizer was employed above the optimum level, implying that fertilizer is been over utilized as indicated by its allocative efficiency ratio of 0.11 . The reason behind over utilization of fertilizer inputs was attributed by the use of lime $\left(\mathrm{CaCO}_{3}\right)$ and dolomite $\left[\mathrm{CaMg}\left(\mathrm{CO}_{3}\right)_{2}\right]$ in large quantities to increase the $\mathrm{pH}$ of mud in bottom of brackish water pond. Therefore, to improve efficiency in shrimp production, the white shrimp farmers should reduce fertilizer in their production.

\section{CONCLUSION}

The study examined the efficiency of resource use in aquaculture farms by small-scale white shrimp farmers in Lamongan Regency, East Java Province, Indonesia. The result indicated that there was inefficiency in the alloca- tions of three inputs, namely labor, fertilizer, feed and stocking density among white shrimp farmers in the study area. Based on the result, the allocative efficiency ratios for labor, fertilizer, feed, and stocking density was 1.94, 0.11, 1.93 and 171.4 respectively. It was concluded that white shrimp farmers were inefficient in the use of aquaculture farm resources. The results reveal that the allocative ratios are greater than unity for labor, feed and stocking density. These ratios show that too little of the respective resource inputs that are labor, feed and stocking density used in white shrimp production process.

Hence, the white shrimp farmers are inefficient in the use of the available factors of production. This implies that production could increased by increasing the use of these inputs. Too little use of the inputs by the white shrimp farmers are reflection of high prices of inputs, lack of credit and inadequacy of cash for purchasing feed and white shrimp fries. Otherwise, fertilizer on white shrimp aquaculture farms was employed above the economic optimum level, implying that fertilizer is been over utilized as indicated by its allocative efficiency ratio of 0.11 .

\section{REFERENCES}

Adewuyi, S. A., Phillip, B. B., Ayinde, I. A., Akerele, D. A. (2010). Analysis of Profitability of Fish Farming in Ogun State, Nigeria. Journal of Human Ecology , 179-184.

Adinya, I. B., \& Ikpi, G. U. (2008). Production Efficiency in Catfish (Clarias Gariepinus) Burchell, 1882 in Cross River State, Nigeria. Continental Journal Fisheries and Aquatic Science, 13-22.

Debertin, D. L. (2002). Agricultural Production Economics, Second Edition. MacMillan.

Dyspriani, P. (2007). Governance and The Study of Shrimp Revitalization Program in Indonesia. Department of Social and Marketing Studies Norwegian College of Fisheries Sciences, University of Troms $\emptyset$.

FAO. (2010). The State of World Fisheries and Aquaculture. Rome: Food and Agricultural Organisation.

Herianto, A. S. (2010). Agricultural Fisheries Extension in Indonesia - Origins, Transportation and Current Challenges. Extension Farming System Journal , Vol. 6 No. 1.

MMAF. (2006). Marine and Fisheries Statistics.
Jakarta: Manister of Marine Affairs and Fisheries Republic of Indonesia.

MMAF. (2010). Marine and Fisheries Statistics. Jakarta: Minister of Marine Affairs and Fisheries Republic of Indonesia.

Nurdjana, M. L. (2006). Indonesia Aquaculture Development. International Workshop on Innovative Technologiesfor Eco-Friendly Fish Farm Management and Production on Safe Aquaculture Food. Bali.

Poernomo, A. (2004). Historical Development of Shrimp Farming and Technology in The Brackish Water Pond. National Symposium on Scientific Development and Aquaculture Technology, (p. 18). Jakarta.

Soekartawi. (2003). Principles of Agricultural Economics, Theory and Its Application. Jakarta: Raja Grafindo Persada.

Ugwumba, C. O. (2010). Allocative Efficiency of 'Egusi' Melon (Colocynthis citrullus lanatus) Production Inputs in Owerri West Local Government Area of Imo State, Nigeria. Journal Agricultural Science, 95100. 